海外文献紹介
特 集

\section{IEEE Computer Graphics and Applications Magazine Exploring Geovisualization}

さまざまな情報を地図に重畳するサービスが注目を集めている中で，海外文献特集では，IEEE Computer Graphics and Applications誌に掲載された地理情報の可視化に関する特集を取り上げる. 本特集は地図生成術や地理情報システム (GIS) だけでなく, 空間的な情報と連携したVirtual RealityやAugmented Reality，および空間的配置と空間認知に関する実験など5編の論文を紹介する. 地理情報の可視化技術は検索エンジンと連携するなど応用範囲が拡大し，ますます重要性が高まっているため，最新技術動向や今後の 展望を占う上でも本特集が読書の参考になれば幸いである.

(海外文献部門委員会委員長 加藤晴久)

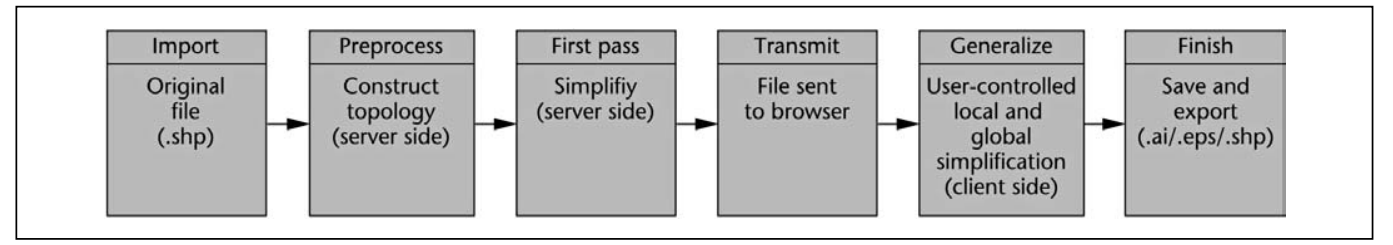

図1 MapShaperは, データ送信とクライアント側の処理のスピードアップのために, サーバ上で多くの処理を行う.

\section{MapShaper.org：地図の一般化のウェブサイト}

1.1 まえがき

マッピングは情報をフィルタリングする初期の方法である。な ぜなら地図は小さいが, 世界は大きく複雑であり, 一般化するこ とを必要とするからである。しかし，データの削減と情報のフィ ルタリングは視覚化の研究で重要な項目である. 地図製作者はグ ラフィックデータのスムージング, 集合化, 簡単化, 移動, 拡張, 分類の有効なテクニックを発展させた.

MapShaper.orgは, リアルタイムに, ベクトル地図データを編 集するためのMacromedia FlashをべースにしたWYSWYGマップ のウェブサービスである. Flashプラグインでウェブブラウザだけ を必要として, 線と形の簡略化とスムージングを提供している. ユーザはマップファイルをアップロードやダウンロードすること ができる.

\section{2 重要事項}

(1) 詳細ポイントの確認

MapShaperでは, ユーザは, ポリゴンかネットワークで詳細な ポイントを確認できる. それは, ユーザに一般的なプロセスを超 えたすばらしい制御を可能にする。

(2) Lossless Generalization and Unlimited Undoes

DPRを実行することですべてのプレビュー状態をためておくこ とができる，そのためユーザはいつも部分的か全体的にステップ をリプレイスし，前もってフィル夕化された空間の詳細をいつで もリカバーできる.

(3) 空間上のブラシと消しゴム

Mapshaperでは, 地図の一部分から詳細をフィルタした空間上 のブラシをつくることができる。このツールはAdobe社の Photoshopのブラシのような機能を持っている(ブラシのサイズを 可変できる). また, 消しゴムはすでに一般化された地図の一部か ら詳細をリカバーできる。

(4) 自動組み立てトポロジー

MapShaperは, どの程度一般的に適用されているかに関係なく，
分かれた境界線と詳細なポイントを保存することができる。

(5) Polylines Converted to Splines

MapshaperはPolylinesとSplinesの両方を認識することができ， それぞれスムージングと簡略化ができる.

\subsection{Mapshaperの構造}

重要な目的の一つに，大きなファイルをリアルタイムに高速で 処理するということがある. 図1に，サーバ側とクライアント側と の処理をあわせたシステム構造の概要を示す.

\section{4 むすびと今後の課題}

Mapshaper.orgは, 今後新しい機能に対応しながら発展してい く．計画としては，例えばPHPトポロジースクリプトをCに変換， サポートしているファイルの大きなリストのインポート，エクス ポートが可能, あいまいなエッジの一般的なブラシを含んだエデ イタとッールの性能の改良などがある。また，エクスポートの間 にメールをサポートする. その先の目的としては，よりパワフル で柔軟性のある簡略化のアルゴリズムの使用を可能にすることで ある. Mapshaper.orgをユーザからの意見を聞きながらGISデー夕 と地図作成の間のギャップを簡単に埋めることができるッールに 発展させたい。

[訳者評] MapShaper.orgは，地図データの簡略化やスムージングに優れ た機能を持っており，今後の性能向上にも大いに期待できる.

(笹近秀樹 委員)

\section{Java3Dを用いたWebベースの3D地理空間データの 視覚化}

\section{1 まえがき}

Webベースの3D地理空間データの視覚化は, 異なるアプリから のデー夕集積や地理データ伝達に効果的であったため長年研究の 対象であり, VRML言語開発やオープンGISコンソーシアム (OGC) によるリレーショナルモデル標準化が行われた。合わせてOracle

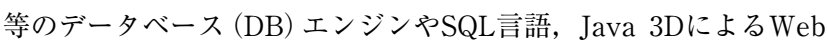


ベース3D視覚化が発展していった.

しかしこれらWebベースッールは, 独自シミュレーションや特 定DBからのデー夕抽出しか行っていなかったため, 我々は, Java3DによるWebベース3D GISプロトタイプとして地理空間DB 視覚化環境 (GeoDOVE) を開発し, リレーショナルDB管理システ ム $(\mathrm{RDBMS})$ への動的接続によりそのユーザビリティ改善の検証 を行った.

\subsection{GeoDOVEのシステム構成と地理情報の視覚化}

Java3Dを用いたGeoDOVEシステムは，PostGISやMy SQL， ArcSDEの三つの地理空間DBエンジンをサポートし, 地理空間記 述言語 (GML) で記述されたファイルを参照して3D空間のレンダ リングを行う（図2）。これらDBエンジンはOGCのSQL簡易特性モ デル（SFS）を採用しており, GeoDOVEの内部地理情報モデルに も実装されている (図3は, SFSクラス構造の図)。JavaによるDB 接続 (JDBC) APIを用いているため, GeoDOVEはあらゆる地理 DBへの接続やSQLクエリ送信, それによるクエリ結果解析等が可 能である．また，JDBCによりデー夕源への書込みも可能となりこ

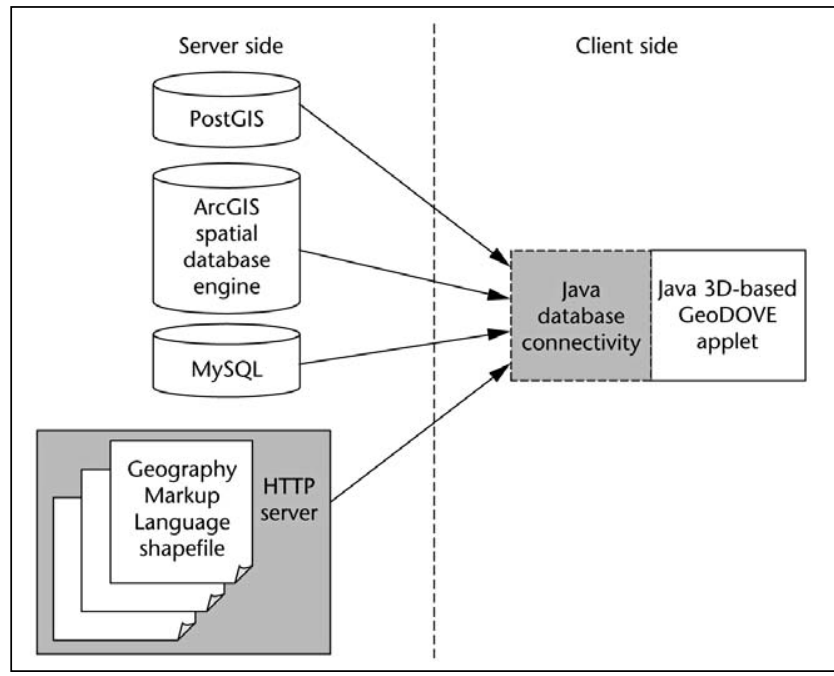

図2 GeoDOVEシステムの構成

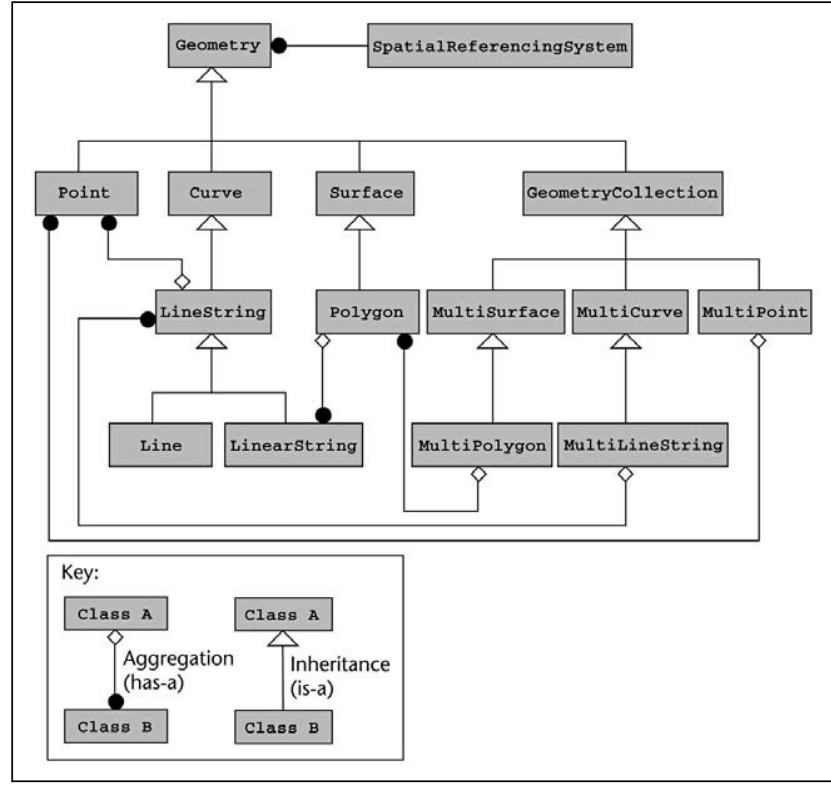

図3ＯGC簡易特性モデルのクラス構造
れによりプロジェクト情報を持続的に更新したり，ユーザ操作履 歴やビューアのラスト位置・方向等を呼び出す事が可能となった.

GeoDOVE内部のSFSモデルは，PointsやPolygons等のクラスに よるベクトル地理データへのインタフェースを定義しており，例 えば，Shape3Dクラスをインスタンス化して3D形状を生成してい る. 図4 (a) は，LineStringオブジェクトによる線描写，図4 (b) は LineStringを成形したLinear Ringオブジェクトによる面描写を示 しており，図5は，Quad Arrayクラスで成形したポリゴンを用い て表現している．また，図6は，ラスタデー夕を用いて高低差を表 現し高度に応じてカラーシェイドを施したものである。このよう に，クラスオブジェクトによる図形描写とベクトル/ラスタデータ による図形計算により，3D描画を行っている.

\section{3 パフォーマンスの評価}

JavaアプレットはJVM上での動作故, ローカル起動の3Dビュー アよりも動作は遅い. 我々は，描画速度が一般ユーザの集中力が 持続する10秒以内か判定することとした.

図7 (a) は，12,500ポリゴン (10MB) のベクトルデータ成形に10 秒，そのアップロードに9秒 (成形とアップロードは同時処理故, 全体で〜10秒), 図7 (b) は, 2,100ピクセル (15MB) のラスタデー 夕のDEM生成に3秒，そのアップロードに10秒弱（すなわち全体で 〜10秒) 掛かることを示している.これらから通常使用において は, Webアプレット上に〜10秒で3Dデータが視覚化されることが 判る.

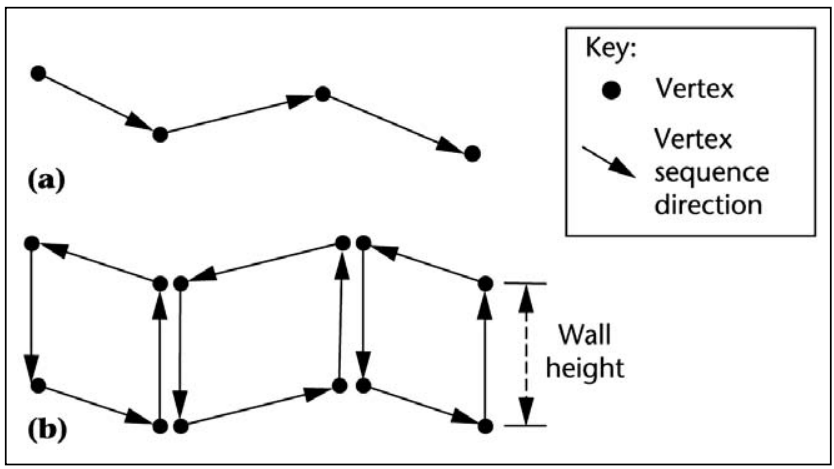

図4 LineStringおよびLinearRingクラスの成形による点の並び (a) 成形前のLineStringによるもの，(b) 成形したLineStringによ る面描写.

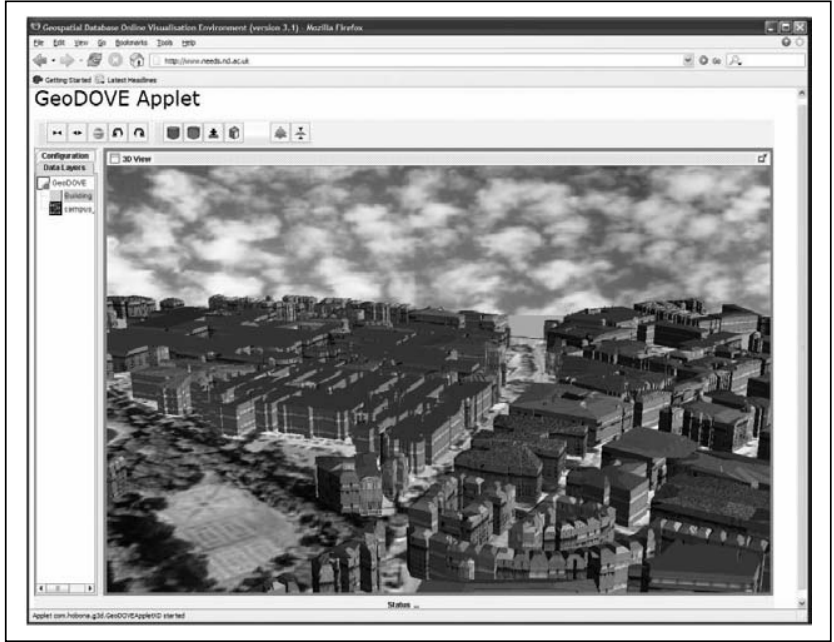

図5 成形ポリゴンによる建造物の視覚化 


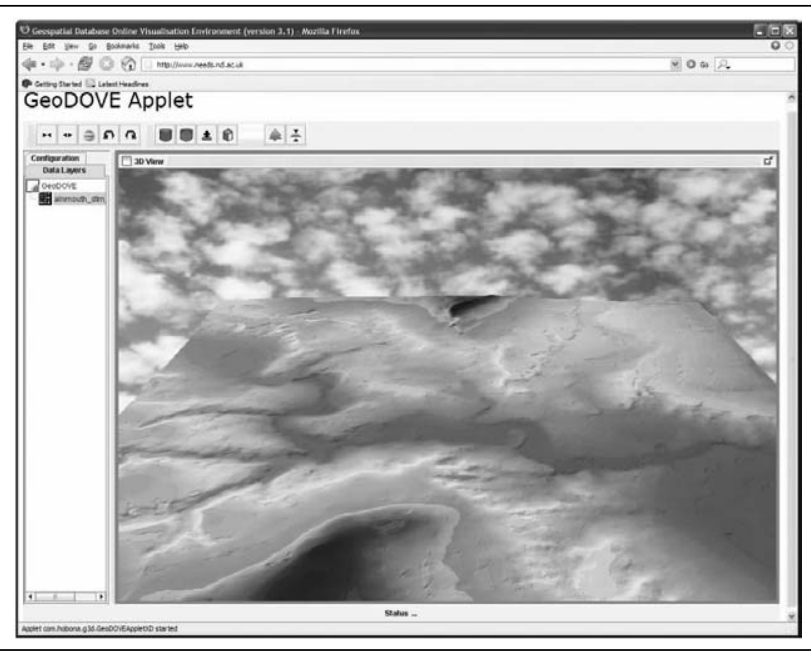

図6 色彩陰影法によるディジタル立面モデル

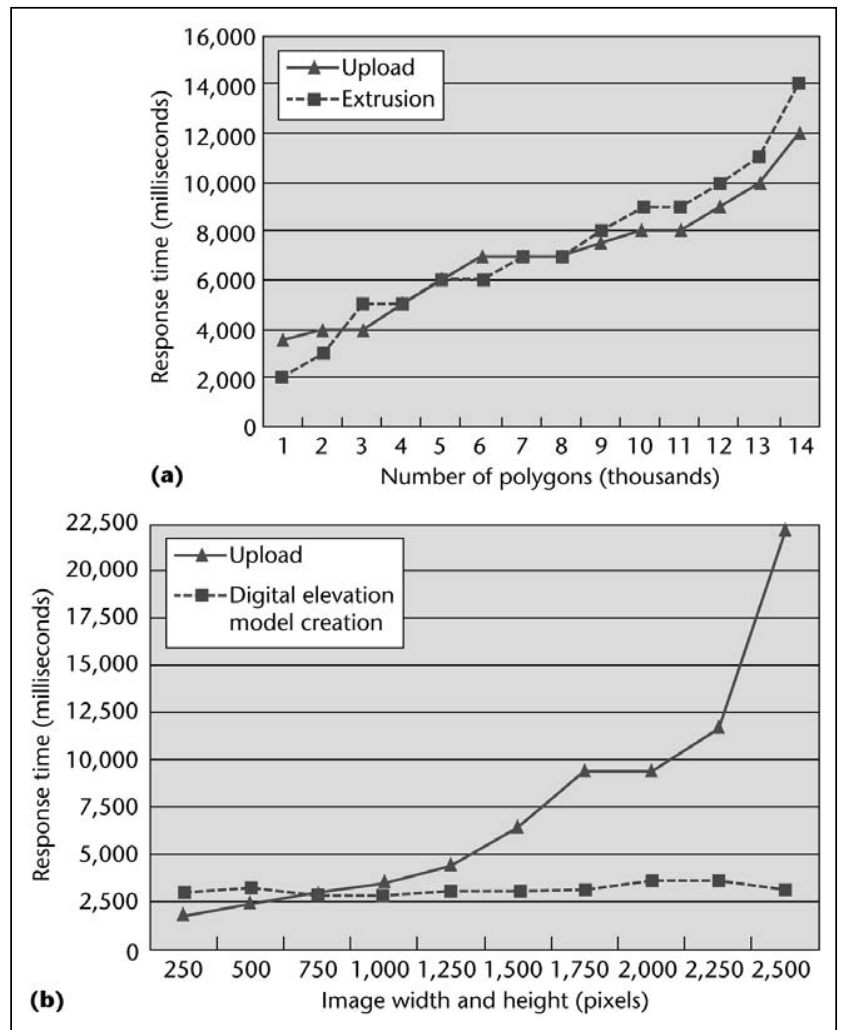

図7 (a)ベクトル層のアップロードと成形の所要時間，(b)ラス夕層 のアップロードとDEM生成の所要時間.

\section{4 結 果}

我々のGeoDOVEは，異なったリレーショナルDBに接続し，ミ ドルウェアの仲介なくRDBMSから直接地理デー夕を読み込むこ とに成功した. また, RDBMSからの地理情報検索中にも3D視覚 化を動的に処理できた。これはJava3Dの使用により, サーバ側で の座標変換や種々の空間デー夕表記処理が可能になったことに加 え, クライアント側でのラスタデータ表記によりロード時間が短 縮されたことによる.

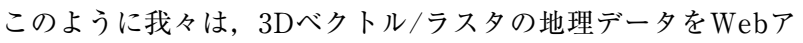
プリケーションにて視覚化するのにJava3Dが有用であることを検 証できた.
[訳者評] Java3Dによる3D視覚化Webアプリを作成し異なったRDBMSへ の接続をサポートしたことで, 汎用DBへのデー夕操作や種々の空間デー夕 表記処理が可能になった点が大いに評価できる.

（三沢天龍 委員）

\section{3. 領域表示空間における距離と類似性のメタファー}

\section{1 まえがき}

空間化メタファーは, サイバースペースのような情報を視覚化 するための一般的なアプローチである。これらの表現はユーザの 直感的な情報空間の探索, 理解に役立つ. 空間化メタファーの一 つである距離と類似性のメタファーでは, 類似物は近接して配置 される. 図8に, 最大のウェブサイトディレクトリである ODP (Open Directory Project)の一部を示す.これに距離と類似性のメ タファーを適用した場合, ウェブサイトのコンテンツの近接したも のは類似性が高く, 離れたものは類似性がそしいことになる。

図8の他の空間化メタファーとして, データの階層性質を表す領 域メタファーがある. 類似ドキュメントを同種テーマ領域に分類 し，色合いにより視覚的に示す。例えば，地図製作者は土壤のよ うな地図デー夕を色合いで表す.

本稿では, 領域表示空間のメタファーの有効性に関する実験的 結果を示し, 領域帰属関係にある空間化メタファーと色で示され る非空間化メタファーが, 距離と類似性のメタファーの効果にど のように影響を及ぼすか解明を試みた。

\section{2 実験内容}

領域表示空間での距離と類似性のメタファーのユーザ解釈につ いての二つの実験を行った。実験1では, 図9のような黒白領域内 の2組のドキュメント点 (Aと1, A と2)の対象間距離と, 領域境界 線と多角形の視覚的特性等を変化させ, 比較点の相対位置関係で

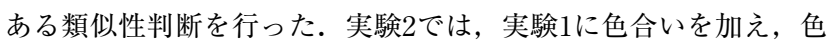
が類似性評価にどのように影響を及ぼすかを検討した。

\section{3 実験結果}

実験1の黑白領域表示空間での類似性判断を調查した結果，領域 帰属関係が対象間距離の効果より優先され, 距離効果を否定する ように作用した．実験2の色領域表示の結果では，色により領域区 別が強化され, 黒白領域の場合以上に色づけされた領域は対象間 距離より優先され判断された. 対象間距離は重要であったが, 領 域帰属関係が主として類似性を決定した。

\section{4 領域関係}

この領域関係が優先される結果は意外な知識ではない.しかし, 分割された領域の類似性判断において, 確立された地図作成設計 原則を実験的に初めて確認したものである.

\section{5 領域表示空間における設計含意}

点, ネットワーク, 表面表示空間からの実験的知見と領域表示 の本実験結果は, 地理情報科学に基づく理論的空間化の枠組みを 充分に立証する。空間メタファー領域は類似ドキュメント集団を 表現するのに有用な概念である.また, 非空間化メタファーの結 果は, カラーネットワーク表示空間による確認から, 空間での地 図作成設計原則の有効性を示す。

\section{6 結 論}

本稿では, 空間表示における点の類似性に他の情報表示設計要 素がどのように影響を及ぼすかを示した，線，領域を内在してい ると同然である視覚場を導入することにより, 点郡のクラスター 化, 配列は類似性判断に効果を生じる.

これらの例は，地図作成設計原則を利用し，空間領域における 設計選択の知覚および認識効果を制御できる設計の枠組みを提供 できることを証明する。 


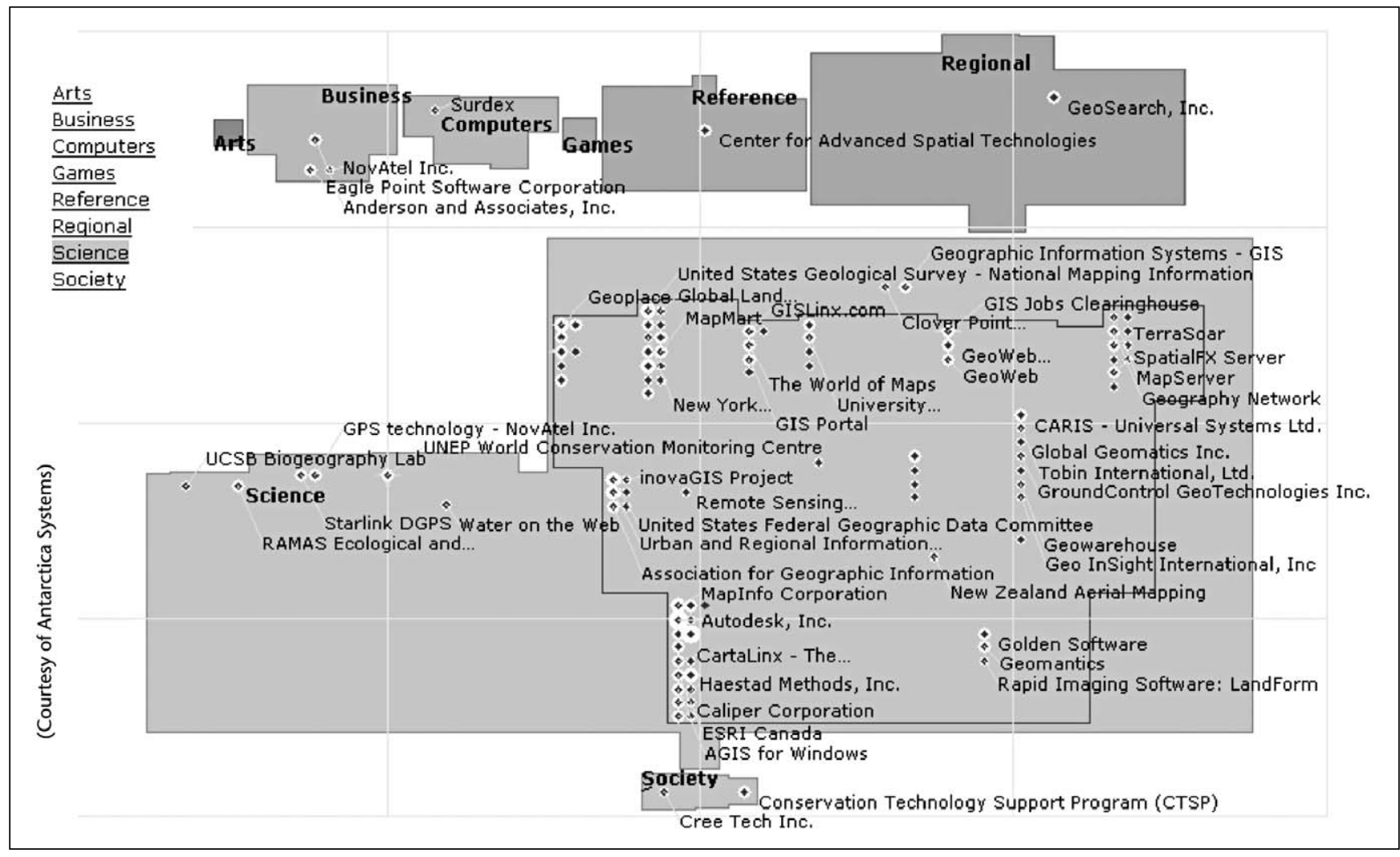

図8 領域表示空間

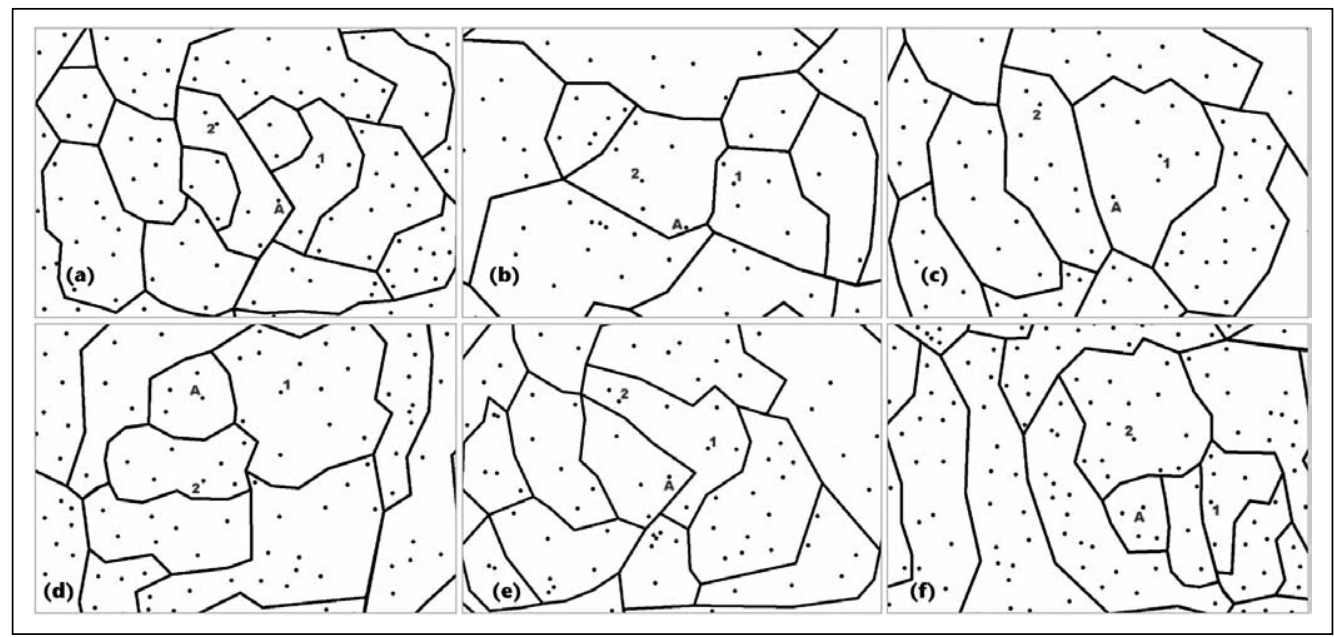

図9 実験1の表示例

[訳者評］空間情報をユーザに正しく伝えるため, 空間情報表現とユーザ 認知の間の関係を正しく理解することは重要であると考える.

(井上 亮 委員)

\section{4. 惑星地質学用没入型仮想野外研究システム}

\section{1 まえがき}

地球の地質学者は野外研究により各地点のデー夕を収集したの ちに, 衛星デー夕を利用して解析する。一方, 惑星地質学者らは 逆順で, 宇宙機が惑星の初期デー夕を得る. 詳細なデー夕が着陸 機や移動車により得られる場合もある. 著者らの目標は, 地球上 と同じ程度に効果的な野外研究を, 他の惑星でも可能とすること
である，著者らは太陽系探査研究における先進的視覚化システム Adviserを開発した。これは高度計, カメラ, 大気その他のデー夕 を用いて，遠隔地域を再構成することで, 地質学者がその地域に 仮想的に入ることを可能にする。ここではシステムと五つのケー ススタデイに基づく観察を述べる.

\section{2 システム概要}

Adviserのプロトタイプ実装は，4面Caveディスプレイを用いて いる．モデル/ビユー/コントローラ型のデザインパターンを利用 し, 地形, カメラ, シミュレーション, ユーザ注釈の各データを モデル化しOpenGLで視覚化した. 80ステレオフレーム/sでレン ダリングした $8,192 \times 8,192$ の高度場に複数の高解像度カメラ画像を 扦入できる. Caveの没入効果で, 地質学者は臨場感を得る. 追跡 


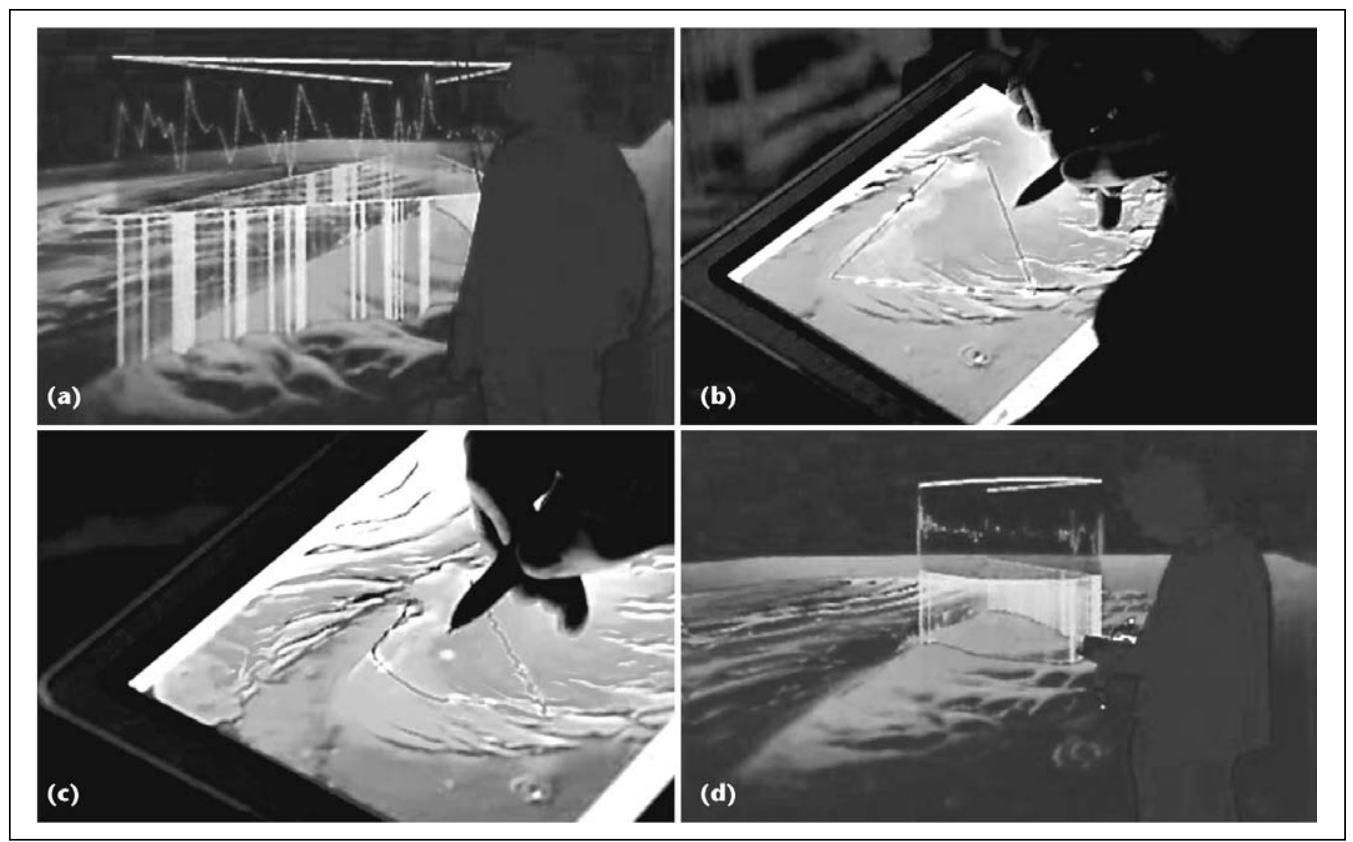

図10 経路計画

(a) 初期の三角形の粗経路のCave内での表示 (垂直線は経路と勾配グラフを結んでいる)，(b) 初期経路のタブレッ トPC表示，(c) 新しい経路の描画，(d) システムが経路と勾配を更新.

された棒状デバイス wandで3D操縦や点指定のような対話的操作 ができ, また, タブレットPCで2次元入力やジェスチャ入力がで きる.典型的には地質学者らは自分のデータによるセッションを 予め研究室で生成しておき，それにCaveでアクセスする。

4.3 ケーススタディ

ケース 1 は一般探査, ケース 5 は風の視覚化である. ケース $2 \sim 4$ は大学院生レベルの研究で, 必要に応じて支援された.

(1) ケーススタディ 1「仮想的野外研究」

Adviserの基本能力はユーザがその地域にいる感覚の体験であ る. 地質学的単位とそれらの全体構造の中の3次元的関係の知見は, 地質学者にとっては重要である. 視点を移動しながら得られる鳥 㒈図群は必須で, 野外ッールキットを用いてこの間のデー夕を記 録できる. 著者らはAdviserを研究と教育に用いた。研究者らは火 星の進化を理解するためのツールとしてはAdviserを利用した. 教 育利用では入門から大学院レベルの授業においてAdviserを使用し た. 例えば「地球, 月, 火星」では, 年間100名をこえる学生が受 講し, 1グループの時間は15分しかなかったので, 操縦以外のッー ルを停止し訓練を短縮した. 内容は学生には好評であった.

(2) ケーススタディ2「火星移動車の経路計画」

経路計画は移動車技術者と地質学者の密接な協力が必要である. これら二者の目標はしばしば対立する. Adviserは効率的な統合協 力環境を提供する. 例えば, 粗い経路を描くと, それを $3 \mathrm{D}$ 地形に 重ねて表示し, カメラ画像も提示する. 技術者がその経路上の勾 配などの変数の評価を選択し, 最大勾配を与えると経路の制約を 満足しない部分を計算し, Cave環境 (図10 (a)) と手持ちのタブレ ットPC (図10 (b)) の両方に提示する. 地質学者が変更した経路を 描画すると (図10 (c)), システムは経路と勾配の視覚化を更新す る $($ 図 $10(\mathrm{~d}))$ 。一般に3D表示は経路の把握を容易にするが, Adviserではさらに, 議論を活性化する. 問題経路の指定には操作 性から地形上の経路へ直接に指定せず, タブレット PC上で2D指定 を用いた。この点はより詳細な評価を予定している。
(3) ケーススタディ $3\lceil$ 方位角・傾斜角測定」

火星において北極の地層の解析は気候変動の研究に重要である. 層解析では同一地層の露出点を多数調べ, それらに最良適合する 面を求め, 方位角と傾斜角を決定する. ユーザがwand操作で点を 追加するたびにAdviserが面を決定し表示する．プロジェクタの出 力品質のためにコントラスト強調がCaveでの視覚化には必要であ った. 地形デー夕を用いて3D地形に層を表示することは, それら の構造と位置づけをを明確化するために役立つ. 仮想レーザポイ ンタでの点指定は難しく, ジョイスティックとの組合せなどの改 良が必要である。

(4) ケーススタディ4「南極ポリゴン計測」

地球の南極のドライバレーは寒冷な極の砂漠で火星に似ている. 地質学者は収縮割れ目によるポリゴン形成と岩屑に覆われた氷河 に沿った構造の変化を研究している. ロボットカメラ画像を地形 罒上に表示し, wandで指定したポリゴンの辺間角度を得ることが できる. Adviserは角度分布をヒストグラム化して表示する，ユー ザは数カ月前の遠征時の考えや疑問を思い出し, 新たなパターン を発見できた.

(5) ケーススタディ5「全球気候モデルシミュレーション」

軌道機による地形および画像データと大気大循環モデルの計算 結果を統合表示できる. 現在はAdviserは離散的格子点において, 風のデータを $3 \mathrm{D}$ 記号として表示した.

\section{4 結 論}

地質学者は, Adviserはただ刺激的なだけでなく3D地形の理解 をより明膫にするとしている. 次の点で有効である.

(1)よりよい空間的判断

(2) $2 D$ D゙ータ視覚化で見落されていた詳細の発見

(3) 効率的な定量的測定

[訳者評] 没入感ディスプレイの科学応用として興味深いが，3次元入力デ バイスが課題である.

(永井 豊 副委員長) 


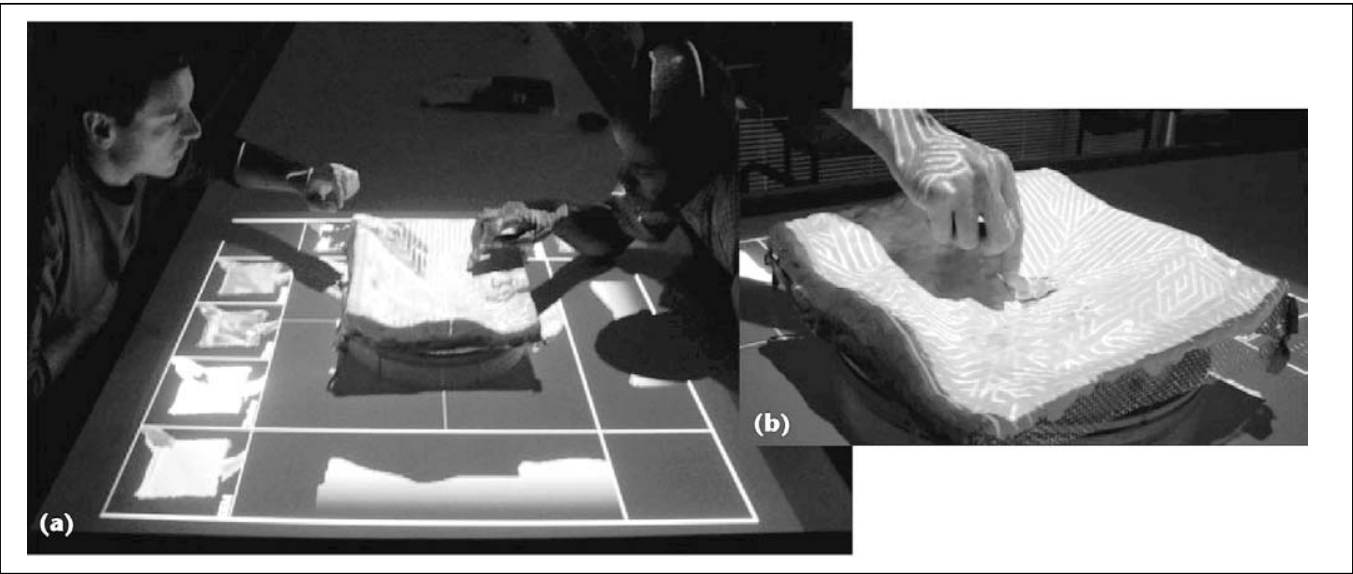

図 11 ユーザは，(a)窪みを形成する，または (b) 砂防ダムを追加することで物理的な景観モデルを変更する，同時 に，流れの向きや色で表現された斜面情報の空間データパターンに変更があると，その影響がモデルサーフェ スに投影される. 一方, その他のパラメータの変化はワークテーブル周辺の小さな2Dイメージとして現れる

\section{5.タンジブル地理空間モデル環境を用いたリアルタイ ム景観データ対話}

\section{1 まえがき}

軍事計画や土地計画には, 何世紀もの間, 直感的で理解し易い ことから3D立体地形モデルが用いられてきた。 それに対して, 仮 想地形モデル環境は高いインタラクティブ性を持ち, ユーザにマ ップレーヤを追加させたり, 視点の位置を選択させたり, モデル 間の飛行などが可能な数值地形デー夕の追加ができる.とりわけ, 3D地理情報処理システム (GIS) と景観の数值モデルの組合せは有 効なッールである。しかしながら，これらッールはシングルユー ザ向けであり, 没入した環境が実世界からの乘離という感情を抱 かせることもある．本論文では過去に開発したタンジブルユーザ インタフェース (TUI) と地形分析研究の成果を踏まえ, もっと直 感的で協力的な景観デー夕対話の概念を紹介する.

\section{2 タンジブルシステム構成とGISとの統合}

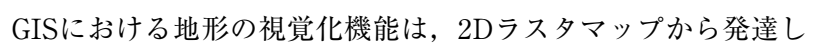
た. Grass GISは3D空間のサーフェスやボリュームの視覚化を提 供した初めてのGIS環境である。また, Illuminated Clay System は，粘土で作り出した地形面上に情報を投影するシステムである. オリジナルのIlluminated Clay Systemは, 景観パラメータの計算 をサポートするため, 地形面解析用のTUIと考えられる. 我々は トポグラフィを超えて, このシステムの利用を拡張するために, 3D物理モデルとGrass GISとの統合を考えた.

水の流れや堆積物の輸送などの動的な景観モデルを扱うには, 特別な配慮が必要である.この場合, ユーザがそのサーフェスと 情報のやりとりを行うと, シミュレートされたプロセスの進展が 変化してしまうからだ。しかしながら, 我々は動的モデルを扱う ことは最も興味深く, 同時に現在の空間情報アプリケーションに 時間相を追加できるので, タンジブルGISの開発で最もやりがいの あるものと考えている.

タンジブル地形データモデリング環境の概念を示すために, Illuminated ClayをGrass GISに統合し, North Carolina 州立大学の 実験場にある分水地点の局所的な氾濫防止と砂防について, さまざ まな構造配置と地形シナリオを探索した. 第1の改良は, 凸状の丘 陵斜面を盆地に形成するという手動変更である. 徐々に, 盆地の形 状を調節して集中していた流れを減少させた。第2の改良は, 小さ なダム状の粘土ピースを用いて砂防ダムの追加を行ったことである
(図11).タンジブルな環境では，ダムの位置や形状・サイズを変更 すると, 擬似リアルタイムに水流への効果を観察することができる. 続いて, 選択されたダムの配置を含む数值地形モデルをGrass GIS にインポートし, 結果として生じる水流の深さと土砂の流量率を評 価した (http://skagit.meas.ncsu.edu/ helena/wrriwork/tangis/ tangis.html).

タンジブル物理モデルとGrass GISの統合は，ユーザに3D景観 データをやりとりさせるタンジブル地理空間モデル環境の構築へ の第1ステップとなる. 我々はアプリケーションの利便性やポテン シャルをもっと理解するために, いくつかの分野をさらに研究す る必要がある. 特に, 物理的な景観モデルの手動操作がサポート できるスケール範囲を調べることや，コンピュータ制御の物理モ デルを結合するためのズームイン機能を追加する可能性を評価す る必要がある. また課題として, 実ワールド空間のモデルデータ をマージすることや, リアルタイムレスポンスと精度がトレード オフの関係にあることが挙げられる.

[訳者評]タンジブル地理空間モデルとGISとの統合によって，3D環境へ の動的変化を直感的に表現できる技術として期待できる。リアルタイム性 脳と分解能などの課題を改善することが重要である. (町田賢司 委員)

\section{〔文 献〕}

1) M. Harrower and M. Bloch: "MapShaper.org: A Map Generalization Web Service", IEEE Computer Graphics and Applications Magazine, pp.22-27 (July/Aug. 2006)

2) G. Hobona, P. James and D. Fairbairn: "Web-Based Visualization of 3D Geospatial Data Using Java3D", IEEE Computer Graphics and Applications Magazine, pp.28-33 (July/Aug. 2006)

3) S.I. Fabrikant, D.R. Montello and D.M. Mark: "The Distance-similarity Metaphor in Region-Display Spatializations", IEEE Computer Graphics and Applications Magazine, pp.34-44 (July/Aug. 2006)

4) A. Forsberg, Prabhat, G. Haley, A. Bragdon, J. Levy, C.I. Fassett, D. Shean, J.W. Head III, S. Milkovich and M.A. Duchaineau: "Adviser: Immersive Field Work for Planetary Geoscientists", IEEE Computer Graphics and Applications Magazine, pp.46-54 (July/Aug. 2006)

5) H. Mitasova, L. Mitas, C. Ratti, H. Ishii, J. Alonso and R.S. Harmon: "Real-Time Landscape Model Interaction Using a Tangible Geospatial Modeling Environment", IEEE Computer Graphics and Applications Magazine, pp.55-63 (July/Aug. 2006) 